\title{
Heavy Metal Contamination and Ecological Risk Assessment in Fluvial Sediment of San Juan -Taxco River System in Mining Region of Taxco Guerrero, Mexico
}

\author{
Edith R. Salcedo Sanchez ( $\sim$ ersalcedo@conacyt.mx ) \\ UAGRO: Universidad Autonoma de Guerrero \\ Manuel Martínez Morales \\ Mexican Institute of Water Technology: Instituto Mexicano de Tecnologia del Agua \\ Juan Manuel Esquivel Martínez \\ UAGRO: Universidad Autonoma de Guerrero \\ Oscar Talavera Mendoza \\ UAGRO: Universidad Autonoma de Guerrero
}

\section{Research Article}

Keywords: Ecological risk assessments, Sediments, Heavy metal, Contamination factor, Pollution load index, Enrichment factor.

Posted Date: August 18th, 2021

DOI: https://doi.org/10.21203/rs.3.rs-785264/v1

License: (c) This work is licensed under a Creative Commons Attribution 4.0 International License. Read Full License 


\section{Abstract}

The hydrological system of San Juan-Taxco Rivers in located inside of one of the oldest and major mining district in Mexico. Several communities in the area use the rivers water along its flow for domestic water supply and crop irrigation. Sediment is an essential, integral and dynamic part of river basins, in polluted environments these act as sink of heavy metals and as a source of contaminants on the fluvial system. The management and sustainability of sediment should be assessed and secured to achieve good ecological status of the basins, for this task, approaches as ecological risk identification and geochemical indices are being used.

Superficial sediment samples were collected in San Juan-Taxco river system. The results demonstrated that the degree of pollution from thirteen heavy metals and metalloids studied decreases in the following sequence: $\mathrm{Cd}>\mathrm{Zn}>\mathrm{Pb}>\mathrm{Cu}>\mathrm{As}>\mathrm{B}>\mathrm{Mn}>\mathrm{Ni}>\mathrm{Fe}>\mathrm{Co}>\mathrm{Ba}>\mathrm{Al}$ and $\mathrm{Cr}$. Cd made the most dominant contribution. Geochemical indices revealed important external anthropogenic influences in the rivers. The geochemical indices indicated very high enrichment for $\mathrm{As}, \mathrm{Cu}, \mathrm{Pb}$ and $\mathrm{Zn}$, and extremely high for $\mathrm{Cd}$ in the three-rivers. The calculation of Pollution Load Index (PLI) showed in Cacalotenago River and in Taxco River are the sites with the highly contaminated sediments. PLI values were very high in all the samples sites due mining tailings erosion, wastewater and agriculture run off. $\mathrm{Cd}, \mathrm{Zn}, \mathrm{Pb}, \mathrm{Cu}$ and $\mathrm{As}$ were the main potential risk elements that will cause harmful biological effects in the riverine environment.

\section{Introduction}

Heavy metal pollution in the rivers systems is one of the major threats for aquatic life and human population due to the abundance, inherent toxicity, persistence, ubiquity, non-degradability, subsequent bioaccumulation and biomagnification in the food chain (Liu et al., 2016; Malvandi, 2017; Rodriguez et al., 2018). The concentration of heavy metals has increased in the environment due to their anthropogenic inputs. Numerous rivers have been polluted with heavy metals from industrial manufacturing processes and mining activities, especially from the inappropriate disposal of wastewater and mine tailings, resulting in negative effects (Morales et al., 2017; Singh and Kumar 2017).

Heavy metals and metalloids discharged into an aquatic ecosystem by both anthropogenic and natural sources; they are dispersed in the different compartments of these ecosystems, such as water, sediment and biota (Ali et al., 2016; Maanan et al., 2015). Once they enter the aquatic ecosystem, only an insignificant portion of free metal ions stay dissolved in water because of the particularities of heavy metals and metalloids, the rest gets deposited and stored in the sediments (Rodriguez et al., 2018; Hernandez et al., 2019). The sediments are an ecologically component of the aquatic system and play a main role in the transport and storage of potentially hazardous metals since they are a potential secondary source of pollutants in the water body (Zheng et al., 2013; Malvandi, 2017;). Metals confined in the sediments can release dissolved and particulate fractions to the water column via hydrodynamic disturbance, chemical and biological processes (Rodriguez et al., 2018).

The ecological risk assessment of river sediment is a suitable technique to investigate the metal contamination (Zahra et al., 2014; Morales et al., 2017; Siddiqui and Pandey, 2019). A number of geochemical indices have been developed and widely used to assess the metal contamination in sediments (Corami et al., 2020; Rodriguez et al., 2018; Morales et al 2017; Malvandi, 2017; Magesh et al., 2011). Geochemical indices such as geoaccumulation index (Igeo), enrichment factor (EF), pollution load index (PLI) to assess the metal contamination and sediment quality guidelines, ecotoxicological values as well as Potential ecological risk index (RI) had been developed to evaluate the ecological risk modelled by metals in sediments. These indices provide useful data that can be easily communicated to local managers and decision makers (Zhang et al., 2018; Siddiqui and Pandey, 2019).

San Juan-Taxco river system represent key resources in terms of providing water for drinking supply, mining industry and agricultural activities (Dotor et al., 2017). Furthermore, in urban areas the rivers usually receive wastewater and surface runoff discharges whilst maintaining recreational and conservation facilities. Mining has been the main economic activity in Taxco region, for five centuries. Ore extraction and heavy metal processing have created wastes posing an environmental threat to the area (Arcega et al., 2009).

The aim of this study was to assess the contamination status of the site through geochemical indices such as Geoaccumulation Index (Igeo), Enrichment factor (EF), Contamination Factor, Pollution Load Index (PLI) and their the potential ecological risk of these metals through Potential Ecological risk Index (PERI) to identify the possible sources of metals a cluster analysis was developed.

\section{Study Area}

The study area is located in the northern part of the state of Guerrero in the municipalities of Taxco and Iguala (Fig. 1). The study area belongs to the Medio Balsas Basin in the Hydrological Region No. 18 and the administrative region IV Balsas (INEGI, 2020). Within the study area is situated the mining district of Taxco recognized for years of mining and processing of precious metals since pre-Hispanic times. In 1522, Hernán Cortés opened in Taxco the first mine of Latin America called "Socavón del Rey" to exploit silver. Silver mining activities continued through the following centuries (Armienta et al., 2004).

The extraction of silver, the main activity of Taxco region, led its inhabitants to undertake the task of working this metal, and there appeared great artists and artisans that today characterize the oldest mining city in the American continent. Already in the 19th century, the silversmiths of Taxco

Page 2/16 
specialized in the manufacture of service pieces (such as plates, jugs, dishes and cutlery for the use of families with the highest purchasing power in the country), as well as objects for religious rites until today with the realization of pieces of jewelry of national distribution and exclusive pieces of export. From colonial times to the present day, in Taxco region silver companies have been familiar; this industry has been growing, becoming an artisan tradition in Mexico for more than 200 years (Clausell, 2010).

This has brought negative impacts on natural resources in the region, with rivers being the most affected resources by the waste from these activities (Talavera et al., 2016). The study area is composed by three rivers. The San Juan (length of $10 \mathrm{~km}$ ), Cacalotenango (length of $11.5 \mathrm{~km}$ ) and the Taxco (length of $29.3 \mathrm{~km}$ ) rivers that jointly discharge at the southern portion of the city of Taxco, also in the town of Taxco el Viejo forming the Iguala or Cocula River (length $75 \mathrm{~km}$ ), and finally discharging into the Infiernillo reservoir (Arcega et al., 2009; Dotor et al., 2014).

The San Juan River receives wastewater from nearby towns, chemical waste from silversmiths for the manufacture of silver crafts and mining tailings (Ramirez, 2013). The Cacalotenango River receives mine waste from La Concha and El Fraile tailings, and urban wastewater without treatment (Romero et al., 2007). The Taxco River receives mine waste from several tailing piles along its flow and receives untreated urban wastewater discharged from the city itself and surrounding localities (Dotor et al., 2014; 2017).

\section{Materials And Methods}

\subsection{Sediment sample collection and analytical procedure}

Seven surface sediment samples were collected in dry season in May of 2019, these samples were taken on San Juan river before its confluence with Taxco River, along the Cacalotenango and Taxco rivers and above and below of their confluence as shown Fig. 1. The samples were collected in plastic bags and kept at $4^{\circ} \mathrm{C}$ until further analysis. In the laboratory sediment samples were air-dried and ground to a fine powder with an agate mortar and then sieved through a 230 ASTM mesh at the Laboratory of Nutrition and Plant Physiology Campus Tuxpan of the Faculty of Agricultural and Environmental Sciences of the Autonomous University of Guerrero (UAGro).

For determining total metals contents, dry-sediment samples were digested in a 1:1 HCl: HNO3 mixture inside a CEM MarxXpress microwave oven (Tessier et al. 1979). Metal quantification was conducted using an inductively coupled plasma optical emission Spectrometer Thermo iCAP 6500 Duo in the Environmental Geochemistry Laboratory of the National Autonomous University of Mexico (UNAM).

The grain size analysis was carried out and the sediment textural classes were deduced according to the Unified Soil Classification System (USCS), ASTM D2487-06 (2006). The measured results were classified into gravel, sand, silt and clay according to the sediment composition. The characterization of mineralogical phases in sediment samples was carried out by X-Ray diffraction, in a Bruker AXS D8 Advance diffractometer to identify the major minerals in sediments samples; this analysis was performed at the Geochemistry Laboratory of Regional School of Earth Sciences of the Autonomous University of Guerrero.

\subsection{Assessment of sediment contamination}

The metal concentrations were compared with the sediment quality guidelines of Canada and threshold effect concentration and probable effect concentration (TEC and PEC). These guidelines allowed a simple, comparative mean for assess the potential risk of pollution in a fluvial aquatic ecosystem (Table 1). The Canadian Sediment Quality Guidelines were designed for the assessment of potential risk, and to assist in determination of the relative priority of sediment quality concerns. The probable effect level threshold (PEL) explains the level above which adverse effects are expected to occur frequently (CCME 1999).

The concentrations below the TEC denote a minimal-effect range, which is considered to identify the contaminant concentrations (conditions) where biological effects are not expected; concentrations equal to or greater than the TEC, but less than the PEC indicate a range where biological effects not commonly occur. Concentrations at or above the PEC means a probable effect range where adverse biological effects often occur (MacDonald et al., 2000).

\subsection{Assessment of metal enrichment in sediments}

\subsubsection{Geoaccumulation index (Igeo)}

The Index of geoaccumulation (Igeo) can be used to evaluate the environmental pollution status compared with geochemical background concentrations (Müller,1969; Corami et al., 2020). The Igeo index is calculated by the following equation:

where is the content of elements in the sediment samples and is the concentration of geochemical background for the same elements (n). The background values of the studied elements used in the calculation this index is the same as those used in the calculation of the contamination factors (CFs) index. Factor 1.5 is the background matrix correction factor due to lithological variations. The Igeo index includes seven classes: Class 
0 (uncontaminated): Igeo $\leq$ 0; Class 1 (Uncontaminated to moderately contaminated): $0 \leq$ Igeo $\leq 1$; Class 2 (moderately contaminated): $1 \leq$ Igeo $\leq$ 2; Class 3 (moderately to heavily contaminated): $2 \leq$ Igeo $\leq 3$; Class 4 (heavily contaminated): $3 \leq$ Igeo $\leq 4$; Class 5 (heavily to very contaminated) $4 \leq$ Igeo $\leq 5$; Class 6 (extremely contaminated): $5<$ Igeo (Varol, 2011; Corami et al., 2020).

\subsection{Enrichment factor（）}

Enrichment factor $(\quad$ ) is a useful indicator reflecting the degree of anthropogenic heavy metal pollution (Sakan et al., 2009). The is calculated using the relationship below:

In the present study, aluminium (Al) was employed as the reference element for geochemical normalization, this element in sediments is useful to eliminate the effect of grain size, since it is a major element, exhibits relatively small content variations and a large distribution.

Interpretation provided by Malvandi et al. (2017) from the EF values were used for the assay, where: EF < 1 indicates no enrichment; < 3 is minor enrichment; $3-5$ is moderate enrichment; $5-10$ is moderately severe enrichment; $10-25$ is severe enrichment; $25-50$ is very severe enrichment; and N50 is extremely severe enrichment (Al Rashdi et al., 2015; Malvandi et al., 2017).

\subsubsection{Contamination Factor (CF)}

The CF index values were obtained by dividing the concentration of each metal in the sediment by baseline or background values (Hakanson, 1980). The background values used were presented in Table 1 and reported by Rudnick and Gao (2014) and Barats (2019).

CF values were explained as follows: low contamination at $\mathrm{CF}<1$; moderate contamination at $\mathrm{CF}<3$; moderate contamination at $1<\mathrm{CF}<3$; considerable contamination at $3<\mathrm{CF}<6$; and very high contamination at CF $>6$, according to Hakanson (1980). The background values (initial concentration) used were 92 for $\mathrm{Cr}, 0.09$ for $\mathrm{Cd}, 628$ for Ba, 774 for $\mathrm{Mn}, 50,400.0$ for Fe, 17.3 for Co, 28 for $\mathrm{Cu}, 47$ for Ni, 67 for Zn, 4.8 for As, 17 for $\mathrm{B}, 17$ for $\mathrm{Pb}$, and 81,500 $\mathrm{mg} \mathrm{kg}^{-1}$ for Al, respectively (Rudnick and Gao 2014; Barats et al., 2019).

\subsubsection{Pollution Load Index (PLI)}

For the entire sampling site, PLI has been estimated by the $\mathrm{n}$-root from the product of $\mathrm{n}$ CFs of the studied metals included:

The PLI for the entire study area can be estimated using the same calculation principle for each sampling point, substituting the CF values for the PLI value of each point, it is determined as the nth root of the product of the $\mathrm{n}$ CF (Contamination Factors) according to Tomlinson et al. 1980:

The index permits a simple, comparative means for assessing heavy metal pollution levels. PLI index of $>1$ is contaminated whereas $<1$ indicates no contaminated (Tomlinson et al., 1980).

Corami et al., (2020) use other evaluation criteria, classifying the degree of contamination for PLI index as follows: PLI < 1 Unpolluted; $1<$ PLI $<1$ Moderately polluted, $2<\mathrm{PLI}<3$ Heavily polluted, PLI $>3$ extremely polluted.

\subsubsection{Potential ecological risk index (PERI)}

Potential ecological risk index method (PERI) was used to evaluate quantitatively the level of the ecological risk degree of heavy metals in aquatic sediments. This index includes eight elements such as: mercury ( $\mathrm{Hg})$, cadmium (Cd), lead (Pb), cupper (Cu), zinc (Zn), and chromium (Cr).

Polychlorinated biphenyls and arsenic (As). PERI was calculated by using the following formula (Hakanson 1980). 
where is the potential ecological risk factor for a given contaminant (i), is the toxic response factor of each element, including $\mathrm{Cr}=2$, $\mathrm{Cu}=5$, $\mathrm{Cd}=30, \mathrm{As}=10, \mathrm{~Pb}=5$ (Hakanson, 1980), and CF are the contamination factors, which have already been described before. The values for each metal were interpreted as follows: $\quad$ low ecological risk; $E_{r}^{i}<40$ moderate ecological risk; ${ }^{40<E_{r}^{i} \leq 80}$, appreciable ecological risk; $80<E_{r}^{i} \leq 160$, high ecological risk; and $160<E_{r}^{i} \leq 320$ serious ecological risk.

The classification according to RI results is as follows: , considerable ecological risk;
, low ecological risk; , moderate ecological risk;

\subsection{Statistical analysis} , very high ecological risk for the studied area.

A cluster analysis was also performed to identify the relationships between the metals in their source. The variables under consideration were thirteen (Al, As, B, Ba, Cd, Co, Cr, Cu, Fe, Mn, Ni, Pb, Zn). The calculations were performed using STADISTICA 10 software (Stat soft Inc., 2011), and considering the Ward's method with Euclidean distances as a measure of similarity (Ward, 1963).

\section{Results And Discussion}

\subsection{Grain size}

According to the grain size analysis results of surface sediments in the study area, sand is the dominant grain size overall. At most sites, the sand content exceeds $80 \%$, the contents of gravel and fine particles (clay and silt) were very small (avg. 6.25 and 2.38\%, respectively). Grain size is significantly influenced by the flow rate and flow velocity of the surface water; the textural parameters derived from the grain size analysis reflect the energy conditions in the sedimentation environment. In a low-energy environment, the sediments are fine, although in a high-energy environment, the sediments are coarse (Kim et al. 2017). In this study, the grain size distribution explains the high-energy environment in the stream producing by the dominance of sand size particles, in which the water flux is high and the slope is steep thereby preventing the sedimentation of fine-grained particles. The sedimentation process occurs on the banks of rivers and in backwaters.

\subsection{Sediment Mineralographic composition}

XRD studies revealed the presence of different minerals as: Quartz, Calcite, Sanidine, Albite, Biotite, Wickenburgite, Lipsconmbite, Phengite, Gypsum and Muscovite. In all the samples a predominance of Quartz crystals (36 to 51\%) and Calcite (6 to 18\%) were shown by XRD; Albite was present in four samples (11.5 to $19.2 \%$ ), sanidine was present in three samples (11. 8 to $13.9 \%)$.

The minerals founded in the sediment samples, the presence of aluminosilicate minerals that are minerals composed of aluminum oxide and silicon dioxide such as Albite, Sanidine, Biotite, Muscovite, Wickenburgite stood out. This is related to the aluminosilicate minerals of igneous and metamorphic rocks are generally unstable in earth-surface weathering conditions, these elements transformed to stable end-products (crystalline clay minerals, oxides and hydroxides) that largely conserve aluminum and iron (Farmer, 1986).

\subsection{Metals concentrations in sediments}

Compared with Canadian Sediment Quality Guidelines (CCME, 1999) for aquatic life protection, metal contents were above the probable effect level (PEL) in $87.5 \%$ of samples for As,75\% for $\mathrm{Zn}, 62.5 \% \mathrm{~Pb}, 50 \%$ for $\mathrm{Cd}$ and $\mathrm{Cu}$ and $25 \%$ for Ni (Table 1 ). The concentrations of heavy metals of sediment samples were contrasted with the TEC, PEC and PEL values, the results are summarized in Table 1 (MacDonald et al., 2000 ). The concentrations of Ni were below the TEC values for $50 \%$ of the samples, indicating that there are no adverse effects in these samples (M1, M2, M3, M7 and M8 samples). The results showed that more than $50 \%$ of the samples were found between the TEC and PEC values for As, Cd, Cu and Zn, indicating that concentrations of these metals occasionally could exhibit adverse effects on the ecosystem. All sites exceeded the TEC levels for As, $\mathrm{Cd}, \mathrm{Cu}, \mathrm{Pb}, \mathrm{Zn}$ demonstrating high level of pollution only M1 is below of TEC value for Pb; in case of Ni two sites exceeded the TEC values (M4 and M6). 
Table 1

Metal concentrations of surface sediments in the study area, background values, Canadian Sediment Quality Guideline values (SQGs), PEL, TEC and PEC used in this study $(\mathrm{mg} / \mathrm{kg})$.

\begin{tabular}{|c|c|c|c|c|c|c|c|c|c|c|c|c|c|}
\hline \multirow[t]{2}{*}{ Sites/SQGs } & Al & As & B & $\mathrm{Ba}$ & $\mathrm{Cd}$ & Co & $\mathrm{Cr}$ & $\mathrm{Cu}$ & $\mathrm{Fe}$ & Mn & $\mathrm{Ni}$ & $\mathrm{Pb}$ & $\mathrm{Zn}$ \\
\hline & \multicolumn{13}{|l|}{$\mathrm{mg} \mathrm{kg}^{-1}$} \\
\hline PEL & & 17 & & & 3.53 & & 90 & 196.6 & & & 75 & 91.3 & 314.8 \\
\hline TEC & & 9.79 & & & 0.99 & & 43.4 & 31.6 & & & 22.7 & 35.8 & 121 \\
\hline PEC & & 33 & & & 4.98 & & 111 & 149 & & & 48.6 & 128 & 459 \\
\hline M1-San Martín & 16771 & $<$ l.c. & 15.8 & 154 & 2.10 & 5.20 & 5.00 & 209.0 & 18637.0 & 231.0 & 18.70 & 35.60 & 351 \\
\hline M2-R. San Juan & 16610.00 & 39.30 & 16.80 & 151.00 & 1.80 & 6.10 & 2.50 & 68.30 & 20009.0 & 362.0 & 16.60 & 94.20 & 144 \\
\hline $\begin{array}{l}\text { M3- } \\
\text { R.Cacalotenango }\end{array}$ & 18313.00 & 48.80 & 12.80 & 173.0 & 16.20 & 7.20 & $<$ l.c. & 78.40 & 20526.0 & 795.0 & 15.70 & 265.0 & 2008 \\
\hline $\begin{array}{l}\text { M4-R. Pte } \\
\text { Tecalpulco }\end{array}$ & 20303.00 & 25.50 & 31.20 & 278.0 & 50.40 & 7.80 & 5.50 & 393.0 & 20614.0 & 2710.0 & 111.0 & 244.0 & 4509 \\
\hline $\begin{array}{l}\text { M5-R. Taxco } \\
\text { Acolco }\end{array}$ & 19032.00 & 24.70 & 15.90 & 104.0 & 5.50 & 7.20 & $<$ l.c. & 41.80 & 23223.0 & 334.00 & 18.6 & 160.0 & 967 \\
\hline M6-El Milagro & 22982.00 & $<$ l.c. & 19.90 & 143.0 & 2.00 & 9.00 & 9.40 & 117.0 & 20930.0 & 105.00 & 24.2 & 13.90 & 142 \\
\hline $\begin{array}{l}\text { M7-R. } \\
\text { Campuzano }\end{array}$ & 12086.00 & 21.30 & 13.80 & 88.0 & 9.40 & 6.30 & $<$ l.c. & 55.90 & 22301.0 & 660.00 & 20.00 & 189.0 & 1763 \\
\hline $\begin{array}{l}\text { M8-R. San Juan } \\
\text { Metlapa }\end{array}$ & 22849.00 & 17.10 & 21.60 & 227.0 & 2.20 & 5.20 & 17.10 & 502.0 & 15366.0 & 298.00 & 15.40 & 32.60 & 811 \\
\hline Mean & 18618.25 & 29.45 & 18.48 & 164.7 & 11.20 & 6.75 & 7.90 & 183.1 & 20200.7 & 686.88 & 30.03 & 129.2 & 1336.9 \\
\hline Max & 22982.0 & 48.8 & 31.2 & 278.0 & 50.4 & 9.0 & 17.1 & 502.0 & 23223.0 & 2710.0 & 111.0 & 265.0 & 4509 \\
\hline Min & 12086.0 & 17.1 & 12.8 & 88.0 & 1.8 & 5.2 & 2.5 & 41.8 & 15366.0 & 105.0 & 15.4 & 13.9 & 142 \\
\hline $\begin{array}{l}\text { Background } \\
\text { values (Rudnick } \\
\text { and Gao 2014) }\end{array}$ & 81500 & 4.8 & 17 & 628 & 0.09 & 17.3 & 92 & 28 & 50400 & 774 & 47 & 17 & 67 \\
\hline SQGs-PEL-Probab & Effect Lev & hresh & & & & & & & & & & & \\
\hline
\end{tabular}

The results also showed values higher than $\mathrm{PEC}$, for $\mathrm{Pb}, \mathrm{Zn}$ and As in 50\%, 37.5\%, 25\% of the samples respectively indicating that adverse biological effects often can be occur. From all selected sites, sample M6 was below PEC and PEL for all metals. For all other sites, As, Zn and Pb found to be the metals of the highest importance due the PEC and PEL values are exceeded for As and $\mathrm{Zn}$ in 6 samples (M2, M3, M4, M5, M7 and M8) and Pb in 5 samples (M2, M3, M4, M5 and M7)

\subsection{Degree of metal enrichment and ecological risk assessment}

The Index of geoaccumulation (Igeo) values are presented in Table 2. The Igeo values of Al, B, Ba, Co, Cr and Fe at all sampled sites were less than zero, suggesting that these sites were not polluted. The values of Igeo for As were greater than 1 but less than 2 in the sediments of M4, M5, M7, and M8, which were classified as moderately contaminated while the samples M2 and M3 were considered as moderately to heavily contaminated. Cadmium was the metal that presented the highest contamination in all the sampled sites, the sediment samples were grouped in heavily contaminated for M1, M2 and M6, heavily to very contaminated for M8 and extremely contaminated for M3, M4, M5 and M7. Zinc, lead and copper are the three metals that have the greatest influence the contamination of river sediments, since they present the highest contamination values of the accumulation index; In the case of zinc, these Igeo values were classified as uncontaminated to moderately contaminated (M2 and M6), moderately contaminated (M1), moderately to heavily contaminated (M5 and M8), heavily to very contaminated (M3 and M7) and extremely contaminated (M4). 
Table 2

The values of Geoaccumulation indices (Igeo) of heavy metals for sediments in San Juan-Taxco River basin.

\begin{tabular}{|c|c|c|c|c|c|c|c|c|c|c|c|c|c|}
\hline \multirow[t]{2}{*}{ Sites } & \multicolumn{13}{|c|}{ Geoaccumulation indices (Igeo) } \\
\hline & Al & As & B & $\mathrm{Ba}$ & Cd & Co & $\mathrm{Cr}$ & $\mathrm{Cu}$ & $\mathrm{Fe}$ & Mn & $\mathrm{Ni}$ & $\mathrm{Pb}$ & $\mathrm{Zn}$ \\
\hline M1-R. San Martín & -2.87 & - & -0.69 & -2.61 & 3.96 & -2.32 & -4.79 & 2.32 & -2.02 & -2.33 & -1.91 & 0.48 & 1.80 \\
\hline M2-R. San Juan & -2.88 & 2.45 & -0.60 & -2.64 & 3.74 & -2.09 & -5.79 & 0.70 & -1.92 & -1.68 & -2.09 & 1.89 & 0.52 \\
\hline M3-R. Cacalotenango & -2.74 & 2.76 & -0.99 & -2.44 & 6.91 & -1.85 & - & 0.90 & -1.88 & -0.55 & -2.17 & 3.38 & 4.32 \\
\hline M4-R. Pte Tecalpulco & -2.59 & 1.82 & 0.29 & -1.76 & 8.54 & -1.73 & -4.65 & 3.23 & -1.87 & 1.22 & 0.65 & 3.26 & 5.49 \\
\hline M5-R. Taxco Acolco & -2.68 & 1.78 & -0.68 & -3.18 & 5.35 & -1.85 & - & -0.01 & -1.70 & -1.80 & -1.92 & 2.65 & 3.27 \\
\hline M6-El Milagro & -2.41 & - & -0.36 & -2.72 & 3.89 & -1.53 & -3.88 & 1.48 & -1.85 & -3.47 & -1.54 & -0.88 & 0.50 \\
\hline M7-R. Campuzano & -3.34 & 1.56 & -0.89 & -3.42 & 6.12 & -2.04 & - & 0.41 & -1.76 & -0.81 & -1.82 & 2.89 & 4.13 \\
\hline M8-R. San Juan Metlapa & -2.42 & 1.25 & -0.24 & -2.05 & 4.03 & -2.32 & -3.01 & 3.58 & -2.30 & -1.96 & -2.19 & 0.35 & 3.01 \\
\hline Mean & -2.74 & 1.94 & -0.52 & -2.60 & 5.32 & -1.97 & -4.42 & 1.58 & -1.91 & -1.42 & -1.62 & 1.75 & 2.88 \\
\hline Max & -2.41 & 2.76 & 0.29 & -1.76 & 8.54 & -1.53 & -3.01 & 3.58 & -1.70 & 1.22 & 0.65 & 3.38 & 5.49 \\
\hline Min & -3.34 & 1.25 & -0.99 & -3.42 & 3.74 & -2.32 & -5.79 & -0.01 & -2.30 & -3.47 & -2.19 & -0.88 & 0.50 \\
\hline
\end{tabular}

Igeo for lead element were categorized as uncontaminated in sample M6, uncontaminated to moderately contaminated in samples M1 and M8, moderately contaminated for sample M2, moderately to heavily contaminated in samplesM5 and M7 and heavily to very contaminated for M3 and M4. For copper Igeo values were classified as uncontaminated in sample M5, uncontaminated to moderately contaminated in samples M3, M4 and M7, moderately contaminated for sample M6, moderately to heavily contaminated in samplesM8 and M4. According to the calculation of each sampling point, the order of the metals according to the lgeo evaluated is as follows: $\mathrm{Cd}>\mathrm{Zn}>\mathrm{Pb}>\mathrm{Cu}>\mathrm{As}>\mathrm{Mn}>\mathrm{Ni}>\mathrm{B}>\mathrm{Fe}>\mathrm{Co}>\mathrm{Ba}>\mathrm{Al}>\mathrm{Cr}$. The critical points associated with the geoaccumulation of metals were M3, M4 and M8; the first with four metals in the range of heavily to very heavily contaminated and the rest with three.

The results from this study show that the Cd enrichment factor, $E F(C d)$, ranges from 78.81 to 2247.94, EF (Zn) from 7.52 to 270.15, EF ( $P b$ ) from 2.9 to $74.97, E F(A s)$ from 12.71 to 45.25 , $E F(C u)$ from 6.39 to 63.95 , $E F(\mathrm{Mn})$ from 0.48 to 14.05 , $E F(\mathrm{Ni})$ from 1.17 to 9.48 , $E F(F e)$ from 1.09 to 2.98 , $E F$ (Ba) from 0.71 to 1.78 , EF (Co) from 1.07 to 2.46 and $E F(C r)$ from 0.13 to 0.66 (Table 3). The average enrichment factors of $\mathrm{Ba}$ (1.14), Co (1.75) and Fe (1.84) are found to be less than $3(\mathrm{EF}<3)$ (Table 3), indicating minor enrichment.

Table 3

The values of enrichment factor (EF) of studied heavy metals for sediments of all sites studied in San Juan-Taxco River Basin

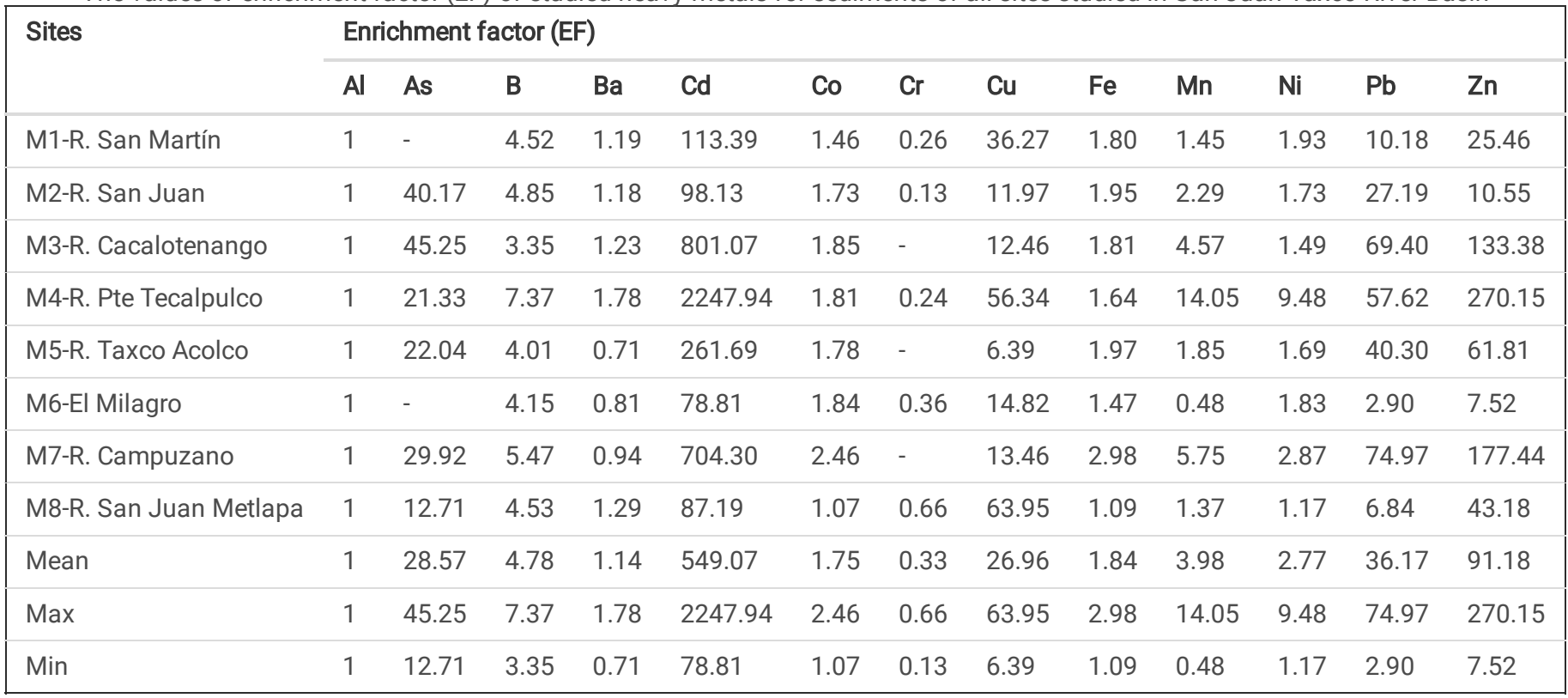

Although the average enrichment factors of B (4.78) and Mn (3.98) are found between 3 and 5 (EF = 3 a 5; Table 3), suggesting that these metal contaminations are currently not a major concern although moderate enrichment; Copper, lead and zinc presented very severe enrichment $(25<\mathrm{EF}<$ 50) and extremely severe enrichment ( $E F>50)$, the average enrichment factors for these heavy metals were 26.96, 36.17, and ranged from 6.39 to 
639, 2.90 to 74.97 and 7.52 to 270.15 respectively. Arsenic in almost all samples sites presented very severe enrichment except for M8 (San Juan Metlapa), with a minimum 12.71 and a maximum 45.25 .

The Cd presents extremely high enrichment in all the points evaluated. The points of attention correspond to the M21, M7, M9, M10 and M17, the first with very severe enrichment with four of the twelve metals and the rest with three of the twelve metals.

The results of contamination factors (CFs) and individual and global pollution load index (PLI) for the sediment from samples sites in the San Juan, Cacalotenango and Taxco Rivers are summarized in Table 4. The CF values for Cd were $>6$ in all the studied sediments, indicating "very high contamination" by Cadmium. The CF values for $\mathrm{Zn}, \mathrm{Pb}, \mathrm{Cu}$ and As present "very high contamination" and "considerable contamination". The CF values for $\mathrm{Al}, \mathrm{Ba}, \mathrm{Co}, \mathrm{Cr}$ and $\mathrm{Fe}$ in all the samples denotes "low contamination" for all the sediments. The critical sites correspond to M3, M4, M5, M7 and M8; the first with four extremely enriched CF values and the rest with three. The level of CF values for each heavy metal in the sediment was in the order: $\mathrm{Cd}>\mathrm{Zn}>\mathrm{Pb}>\mathrm{Cu}>\mathrm{As}>\mathrm{Mn}>\mathrm{Ni}>\mathrm{Fe}>\mathrm{Co}>\mathrm{Ba}>\mathrm{Cr}$. These results indicated that the contamination is relatively high; there are serious impacts of pollution related heavy metals in the nearby areas to abandoned mining tailings and where heavy metals processing (jewelry) is done and untreated sewage. Among all metals, contamination by $\mathrm{Cd}$ is the highest in all the sediment samples in a range of CF values of 20 to 560 .

Table 4

Metal contamination factors (CFs) and Pollution load indices (PLIs) for sediments of all sites studied in San Juan-Taxco River basin.

\begin{tabular}{|c|c|c|c|c|c|c|c|c|c|c|c|c|c|c|}
\hline \multirow[t]{2}{*}{ Sites } & \multicolumn{14}{|c|}{ Contamination factors (CFs) } \\
\hline & Al & As & B & $\mathrm{Ba}$ & $\mathrm{Cd}$ & Co & $\mathrm{Cr}$ & $\mathrm{Cu}$ & $\mathrm{Fe}$ & Mn & $\mathrm{Ni}$ & $\mathrm{Pb}$ & $\mathrm{Zn}$ & PLI \\
\hline M1-R. San Martín & 0.21 & - & 0.93 & 0.25 & 23.33 & 0.30 & 0.05 & 7.46 & 0.37 & 0.30 & 0.40 & 2.09 & 5.24 & 0.796 \\
\hline M2-R. San Juan & 0.20 & 8.19 & 0.99 & 0.24 & 20.00 & 0.35 & 0.03 & 2.44 & 0.40 & 0.47 & 0.35 & 5.54 & 2.15 & 0.862 \\
\hline M3-R. Cacalotenango & 0.22 & 10.17 & 0.75 & 0.28 & 180.00 & 0.42 & - & 2.80 & 0.41 & 1.03 & 0.33 & 15.59 & 29.97 & 2.078 \\
\hline M4-R. Pte Tecalpulco & 0.25 & 5.31 & 1.84 & 0.44 & 560.00 & 0.45 & 0.06 & 14.04 & 0.41 & 3.50 & 2.36 & 14.35 & 67.30 & 2.829 \\
\hline M5-R. Taxco Acolco & 0.23 & 5.15 & 0.94 & 0.17 & 61.11 & 0.42 & - & 1.49 & 0.46 & 0.43 & 0.40 & 9.41 & 14.43 & 1.434 \\
\hline M6-El Milagro & 0.28 & - & 1.17 & 0.23 & 22.22 & 0.52 & 0.10 & 4.18 & 0.42 & 0.14 & 0.51 & 0.82 & 2.12 & 0.718 \\
\hline M7-R. Campuzano & 0.15 & 4.44 & 0.81 & 0.14 & 104.44 & 0.36 & - & 2.00 & 0.44 & 0.85 & 0.43 & 11.12 & 26.31 & 1.593 \\
\hline M8-R. San Juan Metlapa & 0.28 & 3.56 & 1.27 & 0.36 & 24.44 & 0.30 & 0.19 & 17.93 & 0.30 & 0.39 & 0.33 & 1.92 & 12.10 & 1.194 \\
\hline Mean & 0.23 & 6.14 & 1.09 & 0.26 & 124.44 & 0.39 & 0.09 & 6.54 & 0.40 & 0.89 & 0.64 & 7.61 & 19.95 & 1.44 \\
\hline Max & 0.28 & 10.17 & 1.84 & 0.44 & 560.00 & 0.52 & 0.19 & 17.93 & 0.46 & 3.50 & 2.36 & 15.59 & 67.30 & 2.83 \\
\hline Min & 0.15 & 3.56 & 0.75 & 0.14 & 20.00 & 0.30 & 0.03 & 1.49 & 0.30 & 0.14 & 0.33 & 0.82 & 2.12 & 0.72 \\
\hline
\end{tabular}

The PLI values estimated by sampling points ranged from 0.72 to 2.83 (Table 4); These indicate that samples M1, M2 and M6, where PLI was below 1 were classified as unpolluted, the samples M5, M6 and M8 were considered as Moderately polluted but samples M3 and M4 were reported as heavy polluted. For the estimation of global value it were considering all the samples and making correction for points M1, M3, M5, M6 and M7, which are the points in which they do not have concentrations of $A s$ and $C r$, therefore $n=12$, the global value of PLI for the entire study area was 1.29 which makes it a moderately contaminated area (Fig. 2). This indicates that the San Juan, Taxco and Cacalotenango rivers are in a state of contamination due to the influence of the 13 metals evaluated, being $\mathrm{Cd}, \mathrm{Zn}, \mathrm{Pb}$ and $\mathrm{Cu}$ the most influential.

The ecological risk of metals in fluvial sediments of San Juan-Taxco river system were assessed through potential ecological risk indices ( and $\mathrm{RI}$ ) and summarized in Table 5. values for cadmium in all cases indicated low risk, while for As the values were between 35.6 and 101.1 indicating low ecological risk for M8, moderate for M4, M5 and M7 and appreciable for M2 and M3. The values for lead showed low ecological risk in samples M1, M2, M6 and M8, and moderate in samples M3, M4, M5 and M7. In the case of Cu, the values in almost all the samples showed a low ecological risk, but in the M4 a moderate and M8 appreciable ecological risk. In addition, the values of RI at all sites were $>600$, which indicated very high ecological risk for the studied area. 
Table 5

Potential ecological risk indices Er i and RI for studied metals in the San Juan-Taxco River basin

\begin{tabular}{|llllllll|}
\hline & Er i & & & \multicolumn{2}{c}{ RI } & Risk grade \\
\cline { 2 - 6 } & As & Cd & Cr & Cu & Pb & & \\
\hline M1-R. San Martín & & 700.0 & 0.109 & 37.32 & 10.47 & 747.90 & very high \\
\hline M2-R. San Juan & 81.88 & 600.0 & 0.054 & 12.20 & 27.71 & 721.83 & very high \\
\hline M3-R. Cacalotenango & 101.67 & 5400.0 & & 14.00 & 77.94 & 5593.61 & very high \\
\hline M4-R. Pte Tecalpulco & 53.13 & 16800.0 & 0.120 & 70.18 & 71.76 & 16995.19 & very high \\
\hline M5-R. Taxco Acolco & 51.46 & 1833.3 & & 7.46 & 47.06 & 1939.31 & very high \\
\hline M6-El Milagro & & 666.7 & 0.204 & 20.89 & 4.09 & 691.85 & very high \\
\hline M7-R. Campuzano & 44.38 & 3133.3 & & 9.98 & 55.59 & 3243.28 & very high \\
\hline M8-R. San Juan Metlapa & 35.63 & 733.3 & 0.372 & 89.64 & 9.59 & 868.56 & very high \\
\hline Mean & 61.35 & 3733.33 & 0.17 & 32.71 & 38.03 & 3850.19 & \\
\hline Max & 101.67 & 16800.00 & 0.37 & 89.64 & 77.94 & 16995.19 & \\
\hline Min & 35.63 & 600.00 & 0.05 & 7.46 & 4.09 & 691.85 & \\
\hline
\end{tabular}

In summary, the and RI indices for the studied elements in the surface sediment at all sites showed that San Juan, Cacalotenango and Taxco river pose any potential ecological risk with major contribution of As and Cd (Table 5 and Fig. 3). The results of heavy metal pollution in surface sediments of San Juan - Taxco river system indicated that the contamination is relatively high. There are serious impacts of heavy metal pollution, related to mining tailings, these have been washed down by the rain towards the rivers bed in the areas near these deposits, non-point source release that carries toxic elements (with heavy metals content as phosphate fertilizers, insecticides and fungicides, etc.), municipal wastewater and discharge with wastes from workshops of metal processing for handicraft and jewelry. The major steps in the manufacturing process of handicrafts and handmade jewelry include refining and alloying with other metals, smelting process and framing the metals, soldering, palatinate, polished, or etched of the piece. Each task is generally accomplished by the use of some substances and actives of heavy metals as Cd, Zn, Ni. For example, Cadmium (Cd) traditionally has been used in jewelry solders or galvanized with zinc is used too (Clausell, 2010). Among all metals, contamination by $\mathrm{Cd}$ is the highest followed in order of importance by $\mathrm{Zn}, \mathrm{Pb}, \mathrm{Cu}$ and $\mathrm{As}$.

\subsection{Worldwide comparison of heavy metal concentration}

The concentrations of heavy metals of San Juan-Taxco river system were compared with other major polluted rivers in Mexico and worldwide and summarized in the Table 6 . The comparison of the heavy metals concentrations with other Mexican rivers showed that, this system presents higher concentrations of $\mathrm{As}, \mathrm{Cd}, \mathrm{Ni}, \mathrm{Fe}, \mathrm{Cu}$ and $\mathrm{Zn}$ than those reported in the Atoyac river; $\mathrm{Cd}, \mathrm{Cu}$, and $\mathrm{Zn}$ higher than those reported in the Panuco River and exceeds the concentrations of $\mathrm{As}, \mathrm{Fe}, \mathrm{cu}, \mathrm{Ni}, \mathrm{Zn}$ measured in the Coatzacoalcos River.

A worldwide comparison of metal concentrations in fluvial sediments of San Juan-Taxco River system with those from other river environments showed higher concentrations, the comparison with Zarrin-Gol River in Iran in $\mathrm{As}, \mathrm{Ni}, \mathrm{Zn}$ and $\mathrm{Fe}$, the sediment concentrations of $\mathrm{Cd}$, $\mathrm{Cu}$, $\mathrm{Ni}$, $\mathrm{Pb}$ and $\mathrm{Zn}$ in the present study exceed those reported in the Yantze, Yellow, Ganga and Euphrates rivers. 
Table 6

Comparison of metal concentrations with other riverine environments worldwide

\begin{tabular}{|c|c|c|c|c|c|c|c|c|}
\hline & As & Cd & $\mathrm{Cr}$ & $\mathrm{Cu}$ & $\mathrm{Ni}$ & $\mathrm{Pb}$ & Zn & $\mathrm{Fe}$ \\
\hline & \multicolumn{8}{|c|}{ Metal concentrations $\left(\mathrm{mg} \mathrm{kg}^{-1}\right)$} \\
\hline Present study & $\begin{array}{l}17.1- \\
48.8\end{array}$ & $\begin{array}{l}1.8- \\
50.4\end{array}$ & $2.5-17.1$ & $4.3-502$ & $\begin{array}{l}15.4- \\
111\end{array}$ & $2.5-13.9$ & $\begin{array}{l}45.09- \\
142\end{array}$ & $\begin{array}{l}15,366- \\
23,223\end{array}$ \\
\hline \multicolumn{9}{|l|}{ Studies in Mexico } \\
\hline Atoyac River (Morales et al., 2017) & 0.16 & 2.58 & 24.5 & 10.2 & 14.4 & 27.1 & 31.5 & 19,180 \\
\hline Panúco River (Jonathan, et al., 2013) & - & $\begin{array}{l}1.79- \\
1.89\end{array}$ & $\begin{array}{l}17.03- \\
21.69\end{array}$ & $\begin{array}{l}22.58- \\
34.13\end{array}$ & - & $\begin{array}{l}39.01- \\
51.35\end{array}$ & $\begin{array}{l}74.78- \\
122.45\end{array}$ & $\begin{array}{l}11,331- \\
14,575\end{array}$ \\
\hline $\begin{array}{l}\text { Coatzacoalcos River (Ruiz-Fernández et } \\
\text { al., 2012) }\end{array}$ & $5-10$ & - & $29-92$ & $15-30$ & $18-35$ & $11-30$ & $64-109$ & - \\
\hline \multicolumn{9}{|l|}{ World wide studies } \\
\hline Yangtze River (Wang, 2015) & 9.1 & 0.19 & 79.1 & 24.7 & 31.9 & 23.8 & 82.9 & - \\
\hline Yellow River (Ma et al,.2015) & - & $0.1-0.3$ & $\begin{array}{l}61.3- \\
139.5\end{array}$ & $\begin{array}{l}14.1- \\
30.3\end{array}$ & $\begin{array}{l}19.3- \\
34.6\end{array}$ & $\begin{array}{l}15.5- \\
24.6\end{array}$ & $39.9-74.6$ & - \\
\hline Tinto River (García et al., 2012) & 1130 & 2.75 & 56 & 805 & 17 & 2230 & 901 & 11,500 \\
\hline Tigris River (Varol and Sen, 2012) & & 7.9 & - & 2860 & & 66 & 1061 & - \\
\hline Ganga River (Pandey and Singh, 2017) & - & 1.7 & 69.9 & 29.8 & 372 & 26.7 & 67.8 & $31,988.6$ \\
\hline Euphrates River (Salah et al. 2012) & - & 1.9 & 58.9 & 18.9 & 67.1 & 22.6 & 48 & $2,249.5$ \\
\hline Zarrin-Gol River (Mavandi et al., 2017) & 21.91 & - & 37.67 & - & 12.39 & - & 32.68 & 13,751 \\
\hline
\end{tabular}

Concentration of Fe were found higher than the values in Tinto River and Euphrates Rivers (Table 6). The Fe abundance in these sediments has been attributed: weathering, erosion and other natural sources, large-scale human activities (mining release, municipal solid waste and agricultural activities). Cadmium values are considerably high, compared to the other rivers of Mexico and the world as presented in Table 6; the results shown concentrations in all study sites above of the background values and these vales is associated with wastes from: mining and handicrafts and jewelry industry, urban and agricultural runoff. Concentration of $\mathrm{Pb}$ in this study was found lower than the reported in Atoyac, Panuco, Coatzacalcos, Yangtze, Yellow, Tinto, Ganga and Euphrates Rivers. This metal is mainly associated with Fe oxide fraction and shows high retention in sediments. $\mathrm{Pb}$ and $\mathrm{Zn}$ concentrations is attributed that tailings are being washed down by the action of rain towards the riverbed. $\mathrm{Zn}$ is one of the most abundant elements in the sediment of San Juan-Taxco system (Table 6). Those values are higer than the values reported in Atoyac, Panuco, Coatzacalcos,Yangtze, Yellow, Ganga, Euphrates and Zarrin Rivers (Wang et al. 2015; Ma et al., 2015; Pandey and Singh, 2017; Salah et al., 2012).

The rivers in the mining region of Taxco constantly receive trace amount of heavy metals from terrigenous sources weathering of rocks. Continuous or intermittent but relatively higher input of heavy metals to rivers and streams is linked to anthropogenic sources (Armieta et al., 2004; Dotor et al., 2017). The comparison study reveals that globally the average metal concentrations in San Juan-Taxco River system are similar compared to other polluted riverine environments as summarizes in Table 6.

\subsection{Cluster analysis}

The cluster analysis was performed to identify the relationship between the heavy metals in sediment samples (Fig. 4). The first of the cluster group includes $\mathrm{Al}$ and Fe (cluster 1), As, B, Cd, Co, Ni, Ba, Pb, Cu, Mn and $\mathrm{Zn}$ take part of cluster 2. The dendrogram indicates that the first group originates from the minerals present in the study area and group 2 is mainly associated with anthropogenic activities.

\section{Conclusions}

The results revealed that the $\mathrm{Cd}, \mathrm{Zn}, \mathrm{Pb}, \mathrm{Cu}$ and $\mathrm{As}$ concentrations in contaminated sites might cause hazardous effects to the sediment-dwelling organisms. Most abundant minerals identified by XRD were quartz, calcite, sanidine and albite from igneous and metamorphic rocks.

The degree/level of metal enrichment assessed through various geochemical indices reveal significant external influences over the metals Cd, Zn, $\mathrm{Pb}, \mathrm{Cu}$ and As. The enrichment of these metals is related to mining tailings erosion, to the land-based point source discharges, heavy metal processing for handicrafts and jewelry, non-point and urbanization.

The areas identified with the highest pollutant load determined with Pollution load index, they were the closest to the mining tailings and areas with a history of metal processing for handicrafts and jewelry (M3 Cacalotenango and M4 Puente Tecalpulco respectively). PLI values indicates that the Taxco and Cacalotenango rivers are in a state of contamination due to the influence of the 13 metals evaluated, being $\mathrm{Cd}, \mathrm{Zn}, \mathrm{Pb}$ and $\mathrm{Cu}$ the most influential. 
The calculated RI values indicate that $\mathrm{Cd}$ and As contributed majority of ecological risk in San Juan-Taxco River sediments. The single factor of Potential ecological risk index indicates a very high potential risk. Also, anthropogenic sources have contributed significantly to heavy metals concentrations in the study area, while natural sources have contributed only small amounts. The analyses also indicate that the main processes that controlling the pollution are mining tailings erosion with discharge processes, and proportional dilution related to grain-size distribution processes, metal concentrations tend to accumulate in areas with fine sediments with reduced flow rate and flow velocity.

\section{Declarations}

\section{Ethics approval and consent to participate: Not applicable}

Consent for publication: Not applicable

Availability of data and materials: All data generated or analysed during this study are included in this published article.

Competing interests: The authors declare that they have no competing interests.

Funding and Acknowledgements: This work was supported by the Semilla Project, Autonomous University of Guerrero, Mexico.

\section{Authors' contributions:}

Edith R. Salcedo Sánchez: sampling collection, data analysis, geochemical assessment, paper writing and edition.

Manuel Martínez-Morales: Statistical analysis, paper writing and edition.

Juan Manuel Esquivel Martínez: Sampling collection, maps edition and paper edition.

Oscar Talavera-Mendoza: Laboratory analysis and paper edition,

\section{References}

1. Al Rashdi, S., Arabi, A.A., Howari, F.M., Siad, A., (2015). Distribution of heavy metals in the coastal area of Abu Dhabi in the United Arab Emirates. Mar. Pollut. Bull. 97, 494-498. https://doi.org/10.1016/j.marpolbul.2015.05.052.

2. Ali, M.M., Ali, M.L., Islam, M.S., Rahman, M.Z., (2016). Preliminary assessment of heavy metals in water and sediment of Karnaphuli River, Bangladesh. Environ. Nanotechnol. Monit. Manag. 5:27-35. http://dx.doi.org/10.1016/j.enmm.2016.01.002.

3. ASTM D2487-06. (2006). Standard practice for classification of soils for engineering purposes (Unified Soil Classification System), ASTM International, West Conshohocken, PA, ASTM - American Society for Testing and Materials

4. Canadian Council of Ministers of the Environment: 1999, Canadian Environmental Quality Guidelines, Winnipeg, Manitoba, Canada.

5. Clausell Arroyo, María Amparo, (2010). Historia de la plata mexicana ,AAPAUNAM. Academia, Ciencia y Cultura, vol. II, núm. 1, enero-marzo 2010, pp. 24-34.: medigraphic.com/pdfs/aapaunam/pa-2010/pa101f.pdf

6. Corami, F., Morabito, E., Gambaro, A., Cescon, P., Libralato, G., Picone, M., Ghirardini, A. V., \& Barbante, C. (2020). Geospeciation, toxicological evaluation, and hazard assessment of trace elements in superficial and deep sediments. Environmental Science and Pollution Research International, 27(13), 15565-15583. https://doi.org/10.1007/s11356-020-07784-7.

7. Farmer VC. (1986); Sources and speciation of aluminium and silicon in natural waters. Ciba Found Symp. 121:4-23. doi: 10.1002/9780470513323.ch2. PMID: 3743232.

8. Folk, R.L., (1980). Petrology of Sedimentary Rocks. Hemphills Publ Co., Austin, Texas, pp. 170.

9. García J, Aguado J,Morillo I (2012). Heavy metals in sediments from the Tinto River (Spain). Mine Water Environ $243-246$

10. Hernandez-Ramirez, A. G., Martinez-Tavera, E., Rodriguez-Espinosa, P. F., Mendoza-Pérez, J. A., Tabla-Hernandez, J., Escobedo-Urías, D. C., Jonathan, M. P., \& Sujitha, S. B. (2019). Detection, provenance and associated environmental risks of water quality pollutants during anomaly events in river atoyac, central Mexico: A real-time monitoring approach. Science of the Total Environment, 669, 1019-1032. https://doi.org/10.1016/j.scitotenv.2019.03.138

11. Jonathan, M.P., Roy, P.D., Rodríguez-Espinosa, P.F., Sarkar, S.K., Muñoz-Sevilla, N.P., Navarrete-López, M., Srinivasalu, S., Thangadurai, N., (2013). Evaluation of trace element concentration (acid leachable) in sediments from River Pánuco and its adjacent lagoon areas, NE México. Environ. Earth. Sci. 68 (8), 2239-2252. https://doi.org/10.1007/s12665-012-1906-6.

12. Ke, X., Gui, S., Huang, H., Zhang, H., Wang, C., Guo, W., (2017). Ecological risk assessment and source identification for heavy metals in surface sediment from the Liaohe River protected area, China, Chemosphere. https://doi: 10.1016/j.chemosphere.2017.02.029.

13. Kim, S., Lee, K. C., Kim, J. E., Jung, K. Y., Ahn, J. M., Kim, H. G., Lee, I. J., Shin, D. S., \& Yang, D. S. (2017). Change in geochemical characteristics of surface sediments in the Nakdong river main stream. Journal of Environmental Science International, 26(3), 311-324. https://doi. org/10.5322/JESI.2017.26.3.311. 
14. Lin, Y., Han, P., Huang, Y., Yuan, G.-L., Guo, J.-X., Li, J., (2017). Source identification of potentially hazardous elements and their relationships with soil properties in agricultural soil of the Pinggu district of Beijing, China: multivariate statistical analysis and redundancy analysis. J. Geochem. Explor. 173:110-118. http://dx.doi.org/10.1016/j.gexplo.2016.12.006.

15. Liu, J., Yin, P., Chen, B., Gao, F., Song, H., Li, M., (2016). Distribution and contamination assessment of heavy metals in surface sediments of the Luanhe River Estuary, northwest of the Bohai Sea. Mar. Pollut. Bull. 109:633-639. http://dx.doi.org/10.1016/j. marpolbul.2016.05.020.

16. Ma, X.L., Zuo, H.खTian, M.J., Zhang, L.Y., Meng, J., Zhou, X.N., Min, N., Chang, X.Y., Liu, Y., (2015). Assessment of heavy metals contamination in sediments from three adjacent regions of the of the Yellow River using metal chemical fractions and multivariate analysis techniques Chemosphere (24), 144, 264-272. https://doi.org/10.1016/j.chemosphere.2015.08.026

17. Maanan, M.M., Saddik, M., Chaibi, M., Assobhei, O., Zourarah, B., (2015). Environmental and ecological risk assessment of heavy metals in sediments of Nador lagoon, Morocco. Ecol. Indic. 48:616-626. http://dx.doi.org/10.1016/j.ecolind.2014.09.034.

18. Macdonald, D.D., Ingersoll, C.G., Berger, T.A., (2000). Development and evaluation of Consensus-Based Sediment Quality Guidelines for freshwater ecosystems. Arch. Environ. Contam. Toxicol. 39(1), 20-31.

19. Malvandi, H. (2017). Preliminary evaluation of heavy metal contamination in the Zarrin-Gol river sediments, iran. Marine Pollution Bulletin, 117(1-2), 547-553. https://doi.org/10.1016/j.marpolbul.2017.02.035

20. Morales-García, S. S., Rodríguez-Espinosa, P. F., Shruti, V. C., Jonathan, M. P., \& Martínez-Tavera, E. (2017). Metal concentrations in aquatic environments of Puebla river basin, Mexico: Natural and industrial influences. Environmental Science and Pollution Research International, 24(3), 2589-2604. https://doi.org/10.1007/s11356-016-8004-3

21. Müller, G., (1969). Index of geoaccumulation in sediments of the Rhine River. Geo. J. 2, 108-118.

22. Pandey, J., Singh, R. Heavy metals in sediments of Ganga River: up- and downstream urban influences. (2017). Appl Water Sci. 7: 669-1678. https://doi.org/10.1007/s13201-015-0334-7.

23. Ramírez M. (2013). Acuerdos comunitarios para la realización del Programa de saneamiento de las aguas residuales de la Microcuenca del río San Juan Taxco, Guerrero.

24. Rodríguez, P. F., Shruti, V. C., Jonathan, M. P., \& Martinez-Tavera, E. (2018). Metal concentrations and their potential ecological risks in fluvial sediments of Atoyac river basin, central Mexico: Volcanic and anthropogenic influences. Ecotoxicology and Environmental Safety, 148, 10201033. https://doi.org/10.1016/j.ecoenv.2017.11.068

25. Rudnick, R. L., \& Gao, S. (2014). Composition of the Continental Crust. Treatise on Geochemistry, 1-51. doi:10.1016/b978-0-08-0959757.00301-6.

26. Ruiz-Fernández AC, Sanchez-Cabeza JA, Alonso-Hernández C, Martínez-Herrera V, Pérez-Bernal LH, Preda M, Hillaire-Marcel C, Gastaud J, Quejido-Cabezas AJ. 2012. Effects of land use change and sediment mobilization on coastal contamination (Coatzacoalcos River, Mexico). Cont. Shelf Res. 37: 57-65. https://doi.org/10.1016/j.csr.2012.02.005

27. Salah EAM, Zaidan TA, Al-Rawi AS. (2012) Assessment of heavy metals pollution in the sediments of Euphrates River, Iraq. J Water Res Prot. 4:1009-1023. doi: 10.4236/jwarp.2012.412117.

28. Siddiqui, E., Pandey, J. Assessment of heavy metal pollution in water and surface sediment and evaluation of ecological risks associated with sediment contamination in the Ganga River: a basin-scale study. Environ Sci Pollut Res 26,10926-10940 (2019). https://doi.org/10.1007/s11356-019-04495-6

29. Singh, U. K., \& Kumar, B. (2017). Pathways of heavy metals contamination and associated human health risk in ajay river basin, India. Chemosphere (Oxford), 174, 183-199. https://doi.org/10.1016/j.chemosphere.2017.01.103

30. StatSoft, Inc. (2011). STATISTICA (data analysis software system), version 10. www.statsoft.com.

31. Tovar-Sánchez, E., Cervantes-Ramírez, T., Castañeda-Bautista, J., Gómez-Arroyo, S., Ortiz-Hernández, L., Sánchez-Salinas, E., \& Mussali-Galante, P. (2018). Response of zea mays to multimetal contaminated soils: A multibiomarker approach. Ecotoxicology (London), 27(8), $1161-1177$. https://doi.org/10.1007/s10646-018-1974-9

32. Varol M., Sen B., (2012) Assessment of nutrient and heavy metal contamination in surface water and sediments of the upper Tigris River, Turkey. Catena 92:1-10. https://doi.org/10.1016/j.catena.2011.11.011

33. Varol, M., 2011. Assessment of heavymetal contamination in sediments of the Tigris River (Turkey) using pollution indices and multivariate statistical techniques. J. Hazard. Mater. 195:355-364. http://dx.doi.org/10.1016/j.jhazmat.2011.08.051.

34. Wang, H.T., Wang, J.W., Liu, R.M., Yu, W.W., Shen, Z.Y., (2015). Spatial variation, environmental risk and biological hazard assessment of heavy metals in surface sediments of the Yangtze River estuary. Mar. Pollut. Bull. 93(1-2), 250-258. doi: 10.1016/j.marpolbul.2015.01.026.

35. Ward, J., (1963). Hierarchical grouping to optimize an objective function. J. Am. Stat. Assoc. 58, 236-244.

36. Zhang, R., Zhou, L., Zhang, F., Ding, Y.J., Gao, J.R., Chen, J., Yan, H.Q., Shao, W., (2013). Heavy metal pollution and assessment in the tidal flat sediments of Haizhou Bay, China. Mar. Pollut. Bull. 74(1), 403-412. https://doi.org/10.1016/j.marpolbul.2013.06.019

37. Zhang, Z., Lu, Y., Li, H., Tu, Y., Liu, B., \& Yang, Z. (2018). Assessment of heavy metal contamination, distribution and source identification in the sediments from the Zijiang river, China. Science of the Total Environment, 645, 235-243. https://doi.org/10.1016/j.scitotenv.2018.07.026

Page $12 / 16$ 
38. Zheng, S., Wang, P., Wang, C., Hou, J., \& Qian, J. (2013). Distribution of metals in water and suspended particulate matter during the resuspension processes in taihu lake sediment, china. Quaternary International, 286, 94-102. https://doi.org/10.1016/j.quaint.2012.09.003.

\section{Figures}

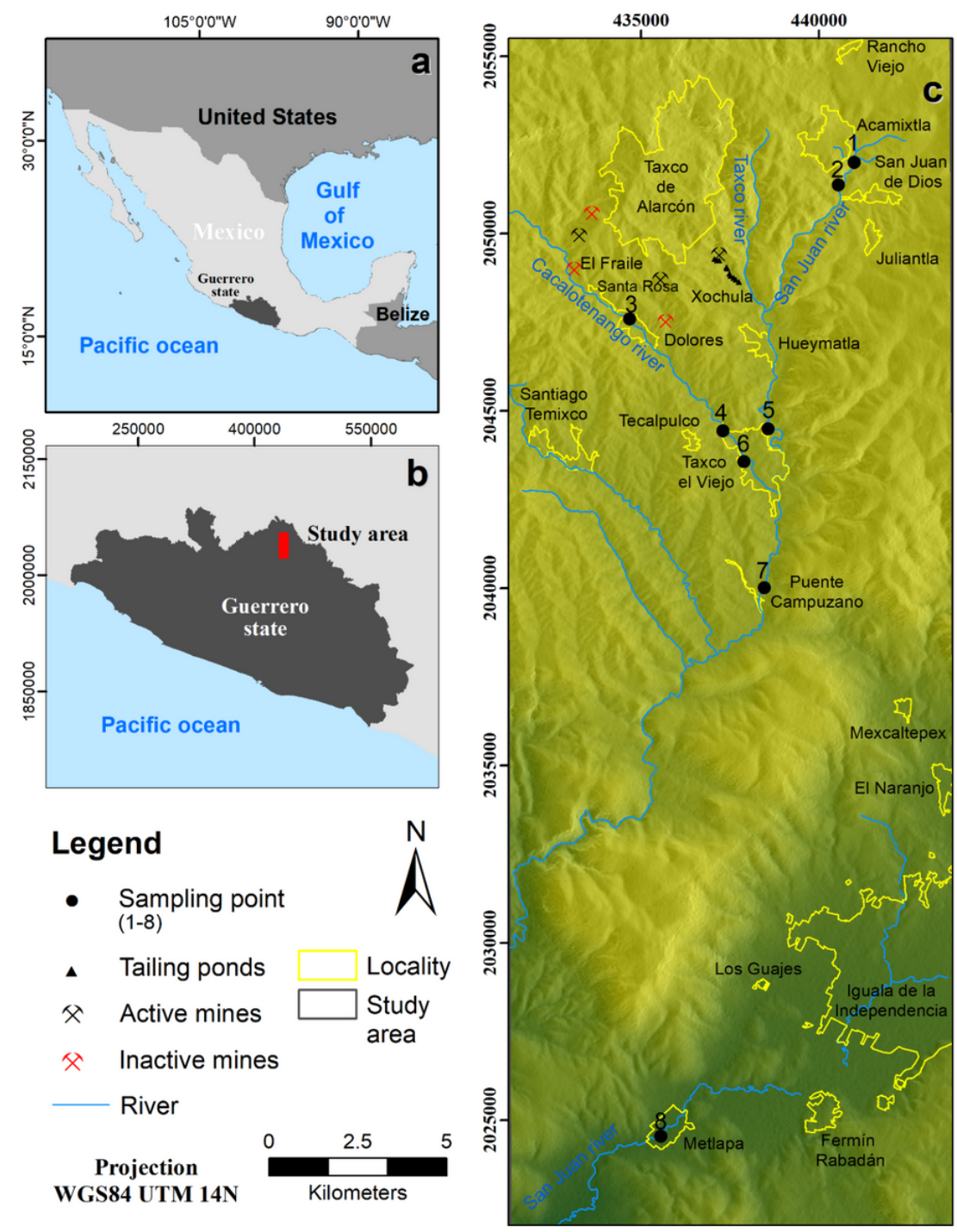

\section{Figure 1}

The location of the study area and sampling sites in the San Juan-Taxco river system 


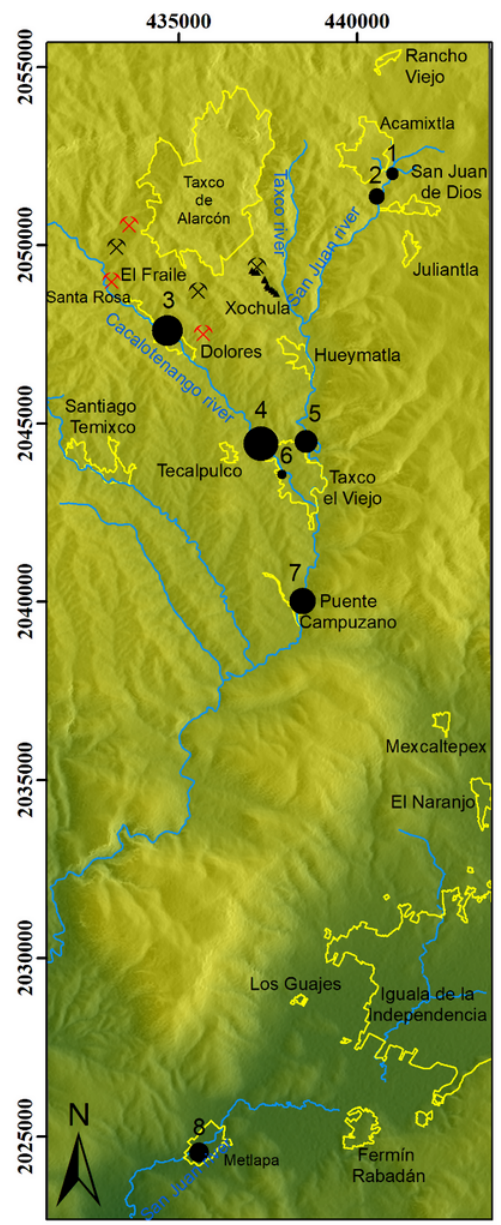

\section{Legend}

PLI

- $\quad$ 0.71. Un polluted

- 0.79 . Un polluted

- 0.86 . Un polluted

- 1.19. Moderately polluted

- 1.43. Moderately polluted

- 1.59. Moderately polluted

2.07. Heavily polluted

2.82. Heavily polluted

- Tailing ponds

父 Active mines

x Inactive mines

- River

Locality

Study area

Projection

WGS84 UTM 14N

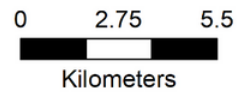

\section{Figure 2}

Pollution load index (PLI) for sediments of all sites studied in the San Juan-Taxco River system 


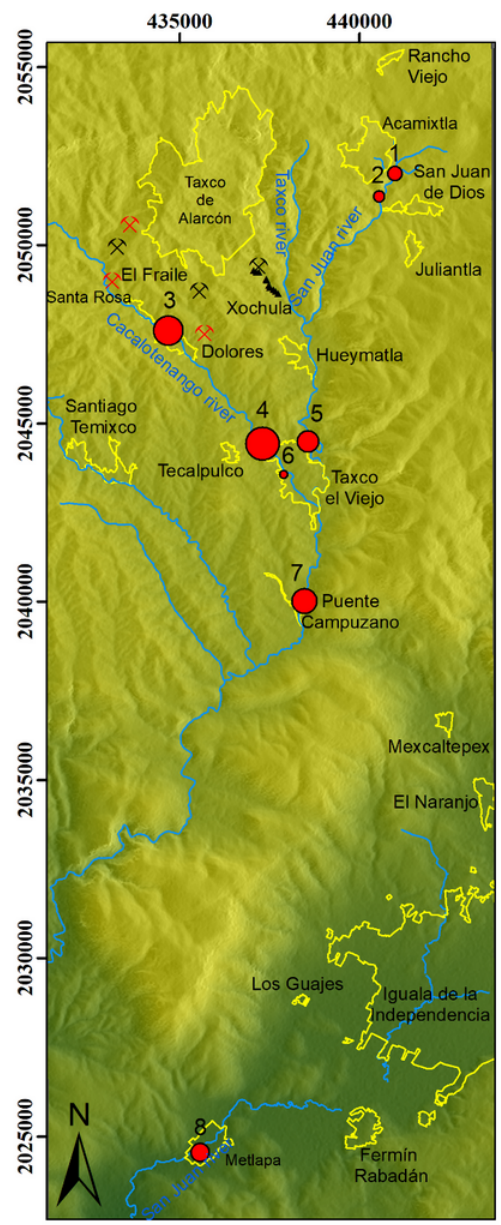

\section{Legend}

Risk grade: Very High

- 691.85

- 721.83

- 747.9

- 868.56

○ 1939.31

O 3243.28

5593.61

16995.19

- Tailing ponds

x Active mines

父 Inactive mines

- River Locality

Study area

Projection

WGS84 UTM 14N

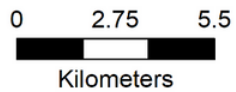

\section{Figure 3}

Potential ecological risk index in the San Juan-Taxco River system

Tree Diagram for 13 Variables

Ward's method

Euclidean distances

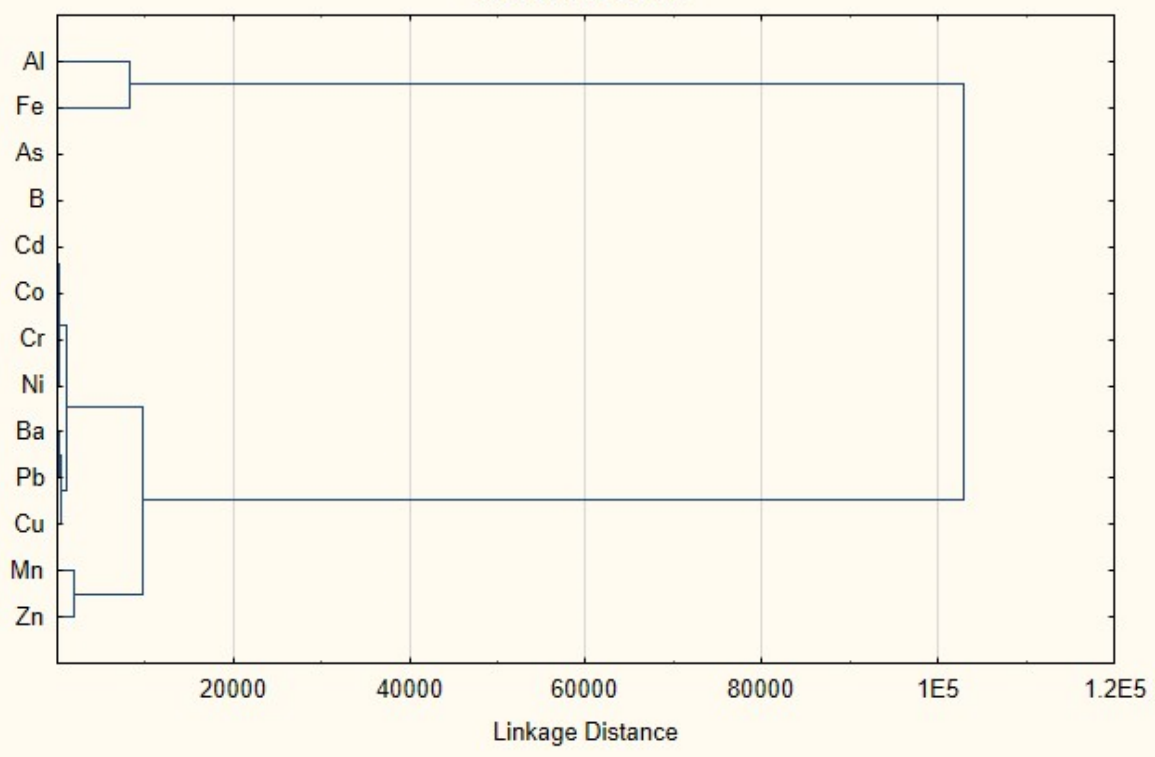

Page 15/16 
Figure 4

Dendrograms showing the clustering of the analyzed metals

Page 16/16 